$$
\begin{gathered}
\text { イセエ゙フィロゾマの飼肖に関する研究一 } I^{* 1} \\
\text { 形態について } \\
\text { 井 上 } \quad \text { 正 昭 } \\
\text { (1977 年 } 11 \text { 月 } 19 \text { 日受理) }
\end{gathered}
$$

Studies on the Cultured Phyllosoma Larvae of the Japanese Spiny Lobster, Panulirus japonicus-I

Morphology of the Phyllosoma

\title{
Masaaki INOUE*2
}

The phyllosoma larvae of Japanese spiny lobster, Panulirus japonicus, was successfully reared in the laboratory up to the last stage of $29.6 \mathrm{~mm}$ in body length, fed on the nauplii and adults of Artemia salina, adults of Sagitta spp. and fish frys of several species, and it took 253 day after hatching.

The developmental state of appendages in each molt of these reared larvae was not always regular. After several molts, the larvae reached the size of next stage. Consequently, each instar did not mean a new stage.

It is not clear whether above mentioned developmental stages were caused only by the unfavorable rearing conditions or whether they actually occur under natural sea conditions as well.

According to the development of appendages and body proportions observed in 112 specimens obtained for this study, phyllosoma larvae of Panulirus japonicus were divided into 11 stages. The characteristics of each stage are described.

In 1963, the author reported that the phyllosoma could be divided into 14 stages since the author assumed that Form E of Panulid phyllosoma named by Oshima would be the same phyllosoma of Panulirus japonicus compared with the specimens obtained in artificially reared larvae. However it was clarified in the present study that this form of phyllosoma is not of Panulirus japonicus but of some other species. Accordingly, the author wishes to correct the number of phyllosoma stages given in his former report.

イセエビ属 Panulirus の初期生活史, 特にフィロゾマ 幼生に関する研究には，大別して二つの方向がある。 そのーつは，自然探集によつてその各 stage の形態と 変熊の過程を追跡し上らとするるので，他の一つは，奻 生の飼育によつてそれらを知ると同時にイ七ニビ增殖の 手段にしようとするものであり，これまで多くの研究 者によつてその採集および飼育が行われた。

しかし，前者の場合には，その初期はともかくとし て，後期に捣いては，採集が容易でなく，種別に各期の 幼生を渞えることが非常に困難であり特に種類数の多い 分布域では，的確にその経過を追跡する事ができない。

一方, 飼育についても，慨料，埕育環境など未知の事 柄が多く、フィロソマを初期から变態期をで飼育した例
はない。

著者は，1956 年以来'72 年まで1)，フルテミヤ Artemia salina と，こ机に各種の你，ヤムシ，ウ二の 畉塊, 魚貝肉の細片などを添加投与して，1971〜’72 年 に上らやく最終期と考兄られる，フィロゾマまでの飼育 に成功した2)。

$$
\text { ここでは，上記の飼育によつて得られたつィロゾマの }
$$

標本から，その形態について述へ，同時に著者ら ${ }^{93}$ が 1963 年に発表した報交中に誴つた解訳をした部分のあ ることが判明したので，その訂正を行うものである。 なお，本研究に淤ける 1966 ’71 年の研究費は，その 1/2 を国費*3により，1959 ＇60 年には，その一部を朝 日科学奖励金によつた。

*1 神奈川紫水産武験場業績

*2 神奈川県水袋場 (Kanagawa Prefectural Fisheries Experimental Station, Misaki, Miura-shi, Kanagawa, Japan).

*B水産庁における指定研究による。 


\section{材料および方法}

瞲育に使つたフィロゾマ奻生は，三浦半島南端の城ヶ

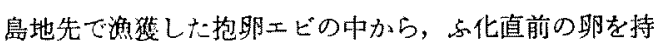
つた親エビを選別し， $0.5 \mathrm{~mm}$ 目のサラン製ネットを張 つた $0.5 \mathrm{~m} \times 0.5 \mathrm{~m}$, 梁已 $0.6 \mathrm{~m}$ の生鐀に収容して心化 させたものである。去の中から所定尾数を飼育水槽に移 して飼育した。

使用した慨料は，年度によつて異なるが，第 1 期から 体長 5 6 mm (第 5 期) 事では，アルテミヤのノウプ リアス（n）あるいはノウプリフスと体長 3〜4 mm の 成体型 (A) とを 1:1 の割合に搌合 (nA) して与え た。な括その投慨密度は常に 4 個体 $/ \mathrm{ml} l^{4)}$ 以上を保つよ らに調整しだ。また1965〜’70 年には上記の外に探集し た仔魚の 50 300 個体/日・飼育水槽, を上記のアルテ ミヤに添加投与し，71 年には，フィロゾマの体長が5 $\mathrm{mm}$ 程度に成长した後，ネット採集したけムシと魚類 の仔魚とを 50 500 個体/日 - 水槽, 添加し, 体長 $10 \sim$ $13 \mathrm{~mm}$ になつたふ化 137 日経過後加ら，人工受精によ つて得たスズキの估魚，151 日経過後からは同じ方法に よつて得たマコガレイ仔魚の 3,000 5,000 個体/日・水 槽，を上記のフルテミヤに添加投与した。

なお，上記のふ化子魚は，いずれもシオミズッボワム シ Brachionus plicatilis を期料比して飼育しながら使 用し，去の体舆はスズキ Lateolabrax japonicus では $4.5 \sim 7.5 \mathrm{~mm}$, マュガレイ Limanda yokohamae では $4.0 \sim 9.5 \mathrm{~mm}$ であつた。
飼育には，1956〜'64 年までは循環式3)または止水方 式をとつたが，'65 年以後には Fig. 1 に示寸回転流水 式の装圈を用いた。

この飼育水槽は， $0.5 \mathrm{~m}^{3} / 12$ 時間を注水した時に，本 槽内の流速が $2 \sim 4 \mathrm{~cm} / \mathrm{sec}$ になるよらに製作した。

飼育水は，経験的に除菌海水による飼育の成績がよい ことから，1956〜'64 年には $75^{\circ} \mathrm{C}$ に加温処理した海水 を使用し，'65 年以後においては Fig. 1 に示す装置を 組立てて，沪過，加温，殺菌，曝気の順に処理した海本 を使用し，飭料子除菌海水で洗浄して投与した。

海水の塩分については，特別な調整を行わなかつた が，その範囲は，塩分 $31 〜 34 \%$ の範囲であつた。 水温は，1956 '59 年には $25^{\circ} \mathrm{C} ， 70$ 年以後には 26 $\sim 27^{\circ} \mathrm{C}$ になるように温度調節を行つた。

なお，剆定，形態観察はすべて生体を用いた。

結果

上記の䝭育過程における観察では，脱皮ごとにその形 態は必ずしも変化しない。特に止水，循環方法で，しか もフルテミヤのノウプリアス単独で飼育したフィロソす は2 回脱皮以後においてその傾向が強いので，instarに 関係なく, 第 1，2 触角, 眼柄, 第 2 小頻, 第 1，2貲 脚の形態，第 3 歩脚特に外肢の発達，第 4, 5 歩脚の出 現とその伸長および形態の変化，各䋶脚と歩脚に晾忛る 基節轓の有無，腹部とその附属器官の発達，頭甲幅と胸 部愊との比などを指標として，形態によつて類別した。 その結果, 今回の飼育に拈けるイセエビのフィロゾ、
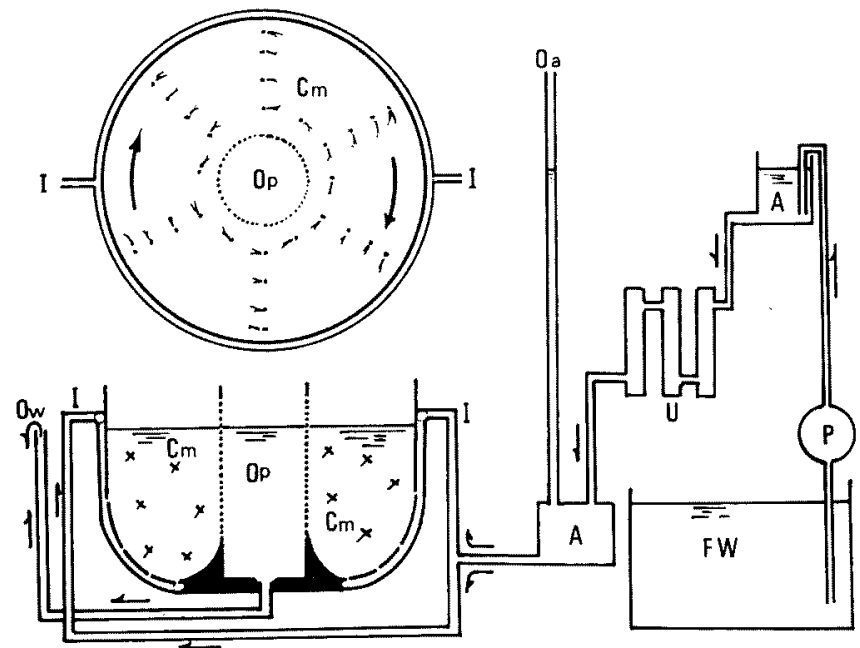

Fig. 1. Scheme of the apparatuus used for culturing the larvae of Panulirus japonicus.

FW: Filtrate. A: Airation and heating. P: Pnmp. U: Ultraviolet rays irradiation. Oa: Outlet of air. I: Inlet of fresh sea-water. $\mathrm{Cm}$ : Culture medium. Op: Outlet of sea water pit. Ow: Outlet of sea-water overflowed. $\leftarrow$ : The arrow show the direction of jet and round-running of sea-water (diameter of jet: $0.5-0.8 \mathrm{~mm}$ ). 


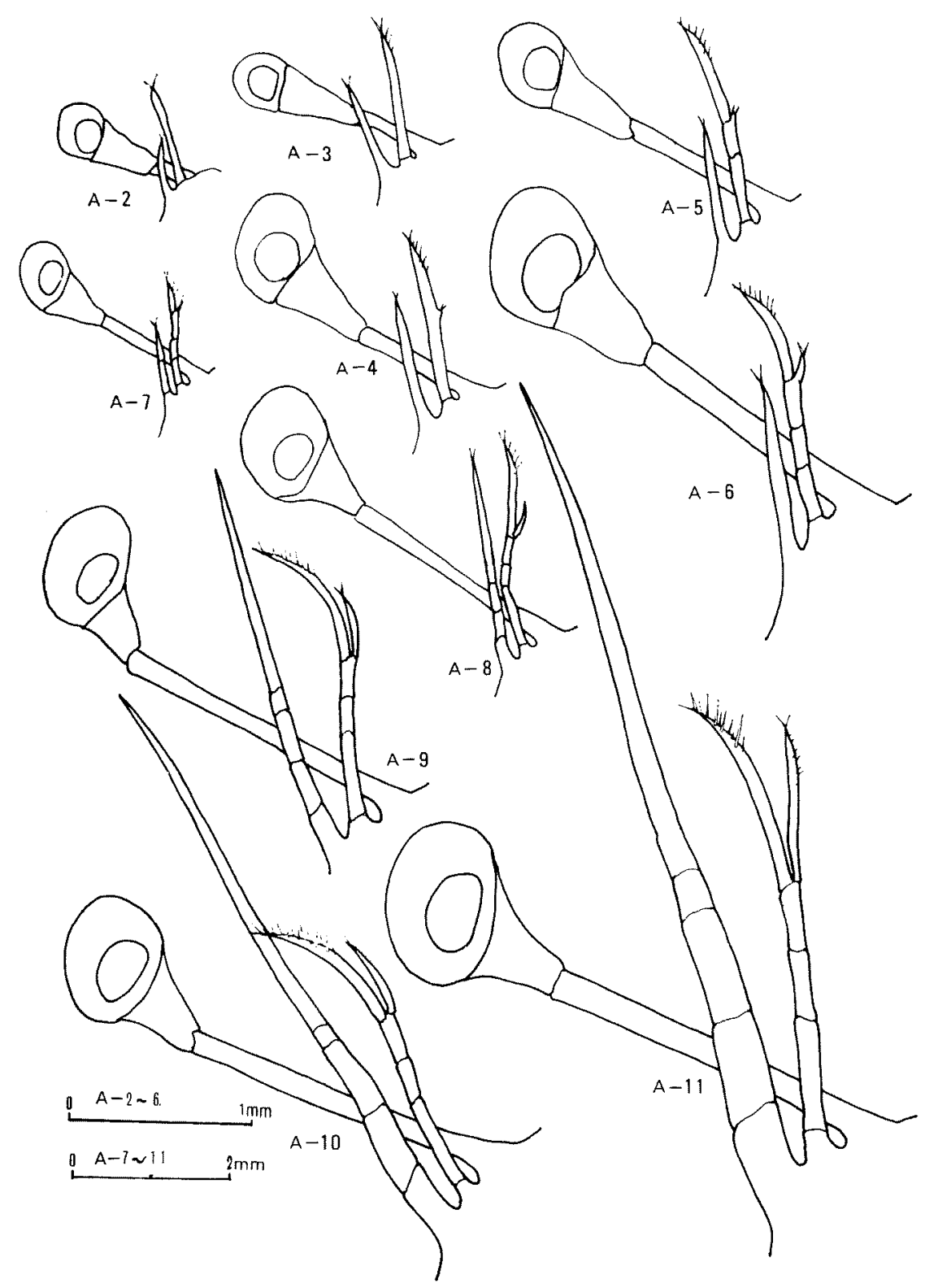

Fig. 2. Development of Antennule, Antenna and Eye in larval stages of Panulirus japonicus. A-2-II: Larval stages.

惊 11 期に類別することがでぎ，その各期の主要な器 官の形態が Fig. 2 4 で，各期の 形態的特徵は次の上 らになる。

第 1 期 (Fig. 5) 占化直後の第 1 期の頭甲は西洋ナシ 型で, その長さと幅の比は $1: 0.870$ である。胸部は頭 甲より幅はせまく，1：0.635で，胸部後方の凹友は顕
著ではないが，第 3 歩踋の基部より腹部の基線が稍々内 側にある。

第 1 触角は，その基部に 1 分節が観察されるが第 2 触 角には分節がない。その長さは, 第 1 触角に比較して短 wo

また，眼柄は分離せず，第 2 小㖽には 4 本の小栜を有

II*詳細については続報で報告する。 


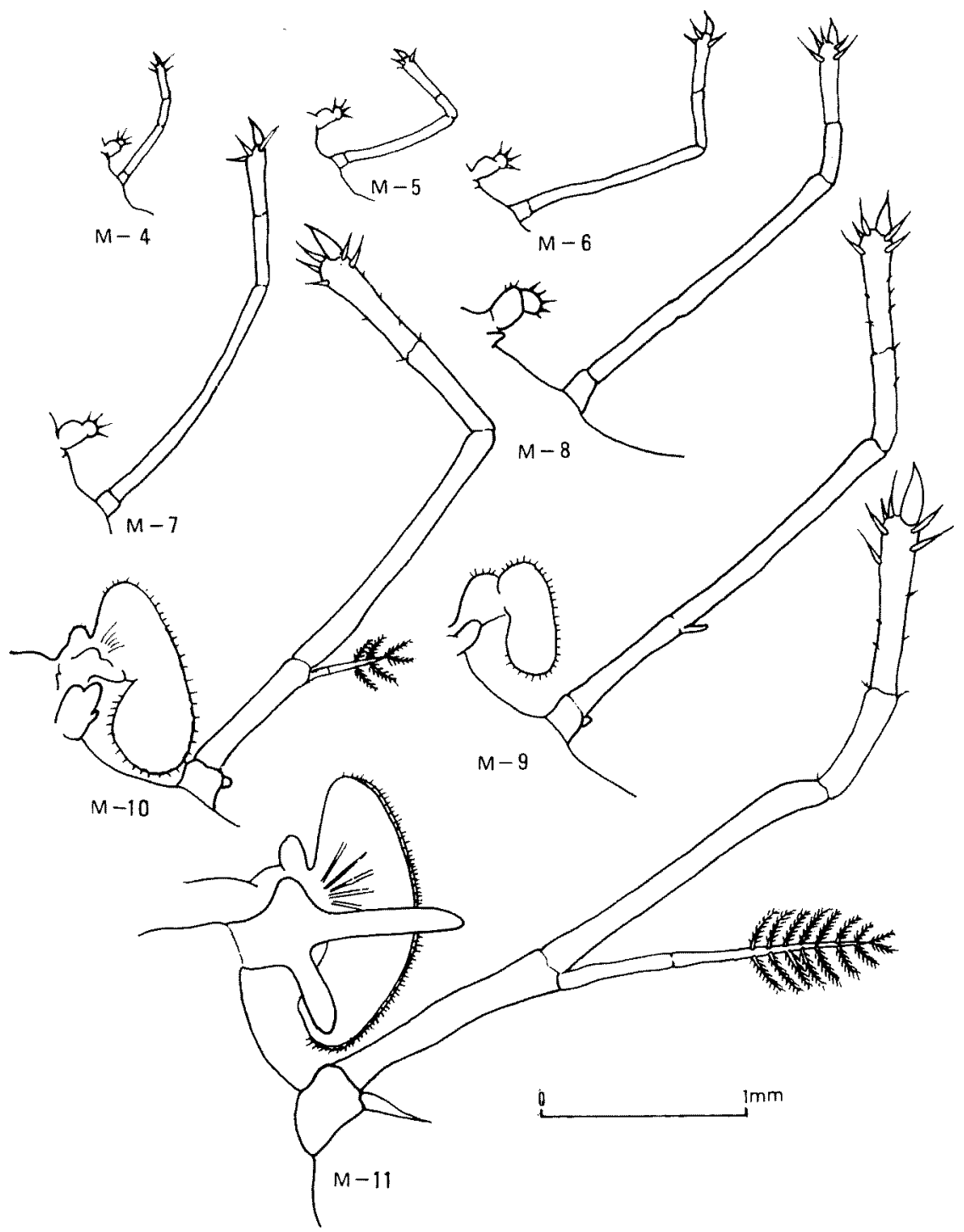

Fig. 3. Development of Maxilla, fiast and second Maxillipedes in larval stages of Panulirus japonicus. M-4-11: Larval stages.

し，第 1 顎脚は第 2 小䫟の基部に脹みとして認められ， 第 2 靧脚には，座節と長節の区分がなく，外肢，基節棘 ともに認められないが，第 3 顎脚には 3 対の遊泳楝毛の ある外肢括上び基節棘を具える。

第 1，2 歩脚はほぼ完成しているが，第 3 歩脚の外肢 は突起状で関節の区分がなく未完成である。なか，第 1 .2 歩脚の外肢には 1 分節があつてその先端側には各 々 5 対 遊泳料毛がある。

腹部は細くて短く，腹肢，関節および尾脚などは，そ の痕跡も認められず，その長さは体長の約 1/6である。
第 2 期 (Fig. 6) この期の特徵は，Fig. 2,A-2 に示 すように短いが眼柄が分離する。頭甲は第 1 期に比較し て細長く，長さと幅との比は，1:0.780で，頭甲䒇と 胸幅との比は $1: 0.676$ で胸部の伸長率がやや大きい。

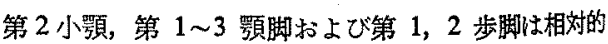
に成長するのみで目立つた変化はないが (Fig，6)，第3 顎脚，第 1.2 歩脚の遊泳棘毛は各々 3，6，6対江增加 する。なお，節による区分はないが，第 3 歩脚の外肢は 伸長し (Fig. 4, Ab-2)，第 1 期の 2 2.5 倍となつて肉 眼的にす第 1 期との区別ができる。 


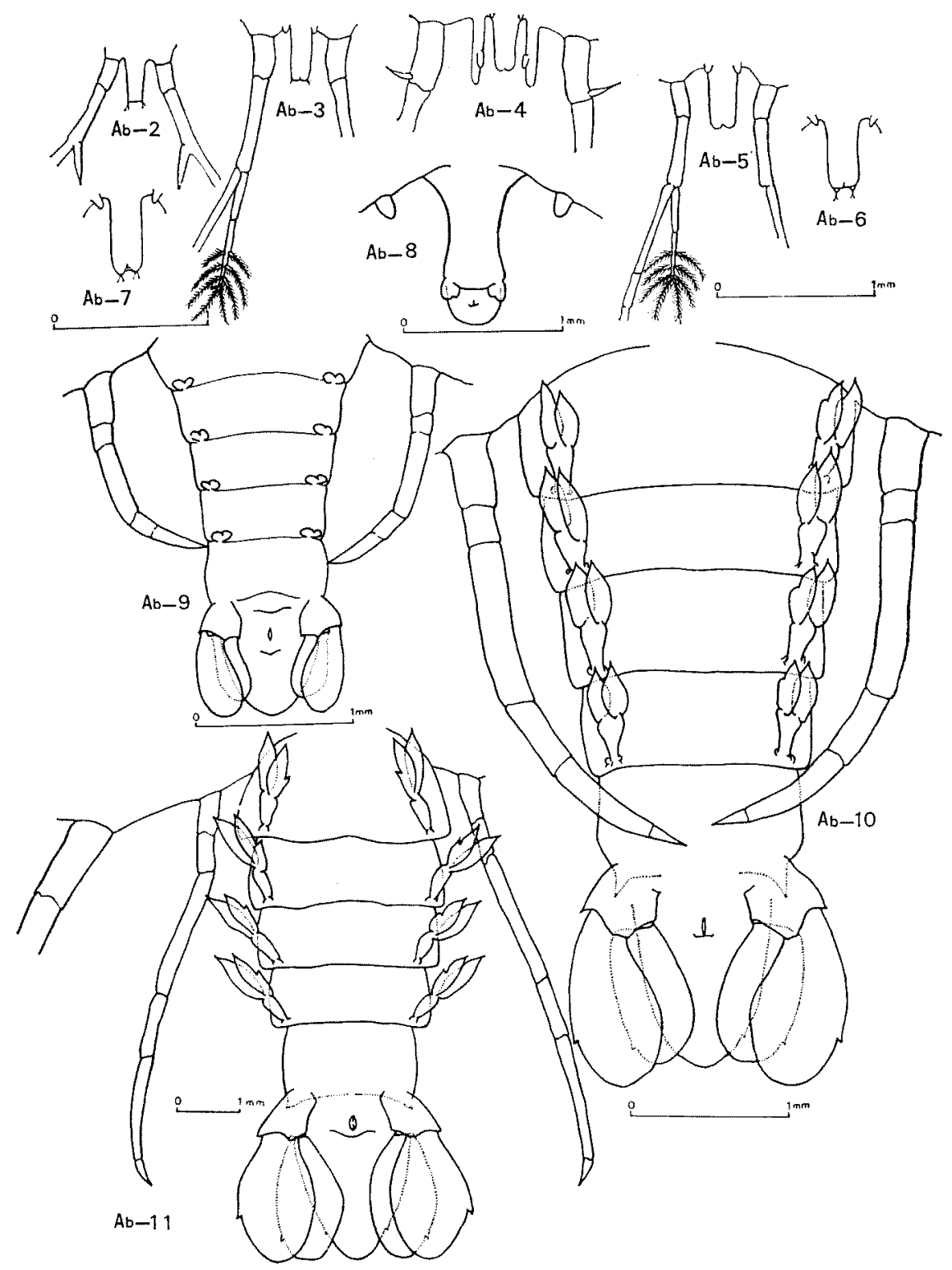

Fig. 4. Development of Abdomen and Pereiopods in larval stages of Panulirus japonicus. Ab-2-11: Larval stages.

腹部 (Fig. 4-Ab-2) は僅かに伸長するのみで変化は 見られない。

第3 期 (Fig. 7) 触角 (Fig. 2, A-3) 怯，第 1.2 之 すに变化せず，第 1 触角外颢の起源も認められない。

頭甲の長さと幅の比仕 $1: 0.720$ で, 胸幅とは 1 : 0.825 で，頭甲幅と胸幅との差は更に縮少する。

第 2 小顎, 第 2 3 額脚および第 1 2 歩脚は伸長す るのみで目立つた亲化はないが，第 2 顎脚，第 $1 \sim 2$ 歩

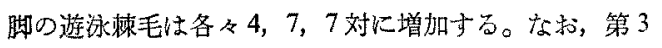
顎脚の基節棘恃それを欠く個体がある。第 3 歩脚（Fig. 4, Ab-3) の外肢惊伸長と同時に節で区分され，1 分節 とその先湍側に 3 4 対の遊泳棘毛が出現する。市た， 一つの特徽として第 4 歩脚が腹部に接してその基部に突 起状に出現する (Fig, 4, Ab-3)。腹部恃僅か飞伸長す るのみて変化は見られない。

第 4 期 (Fig. 8) 頭甲の長さと幅の比は 1:0.603 で 


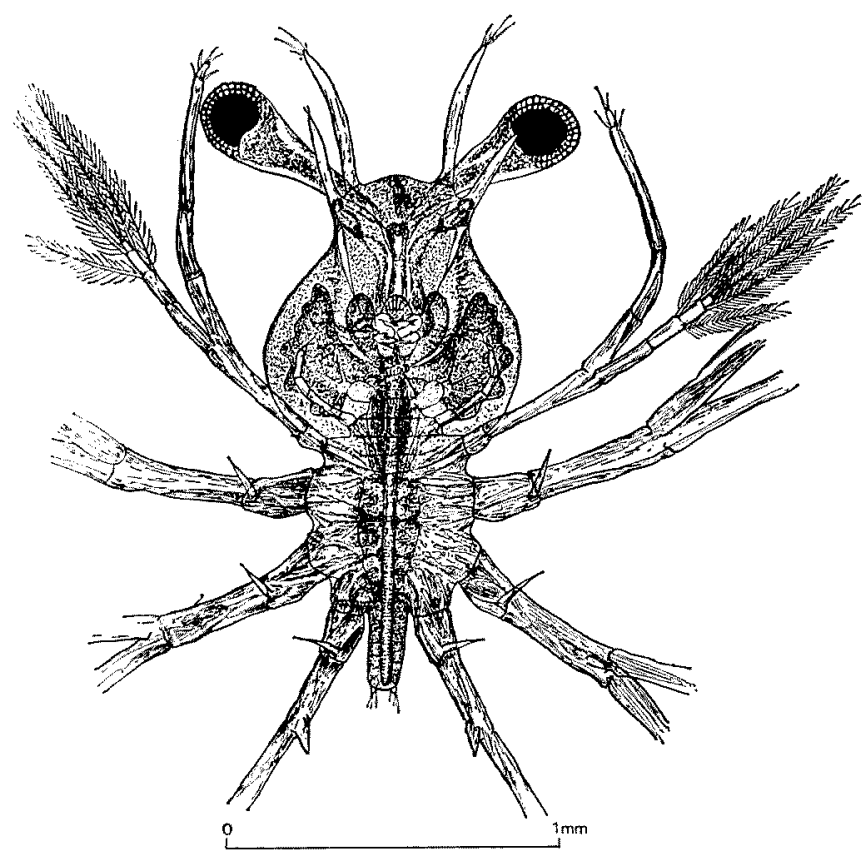

Fig. 5. First stage of Panulirus japonicus phyllosoma in ventral view.

更に細長く变化し，頭甲愊々胸幅とでは 1:0.993でほ ぼ同幅となり，触角は第 1 触角の中央部内側が僅かに突 出して，外鞭の出現する徽候が見られるが (Fig. 2, A4)，分節は認められない。第 2 触角にも変化は見られな い。

第 2 小顎, 第 $1 \sim 3$ 顎脚は，第 $1 \sim 3$ 歩脚とともに形 態の変化はないが，第 3 顎脚と第 $1 \sim 3$ 步脚の遊泳萰毛 は更に增加する。しかしその対の数はこの期頃から不挸 則となる。

第 4 歩脚は伸長し，腹部の基部から左右外侧入移動 し，腹部の 1/2 乃至腹部より僅かに長くなり，外肢が突 起状に認められる (Fig. 4, Ab-4)。しかし外肢の認め られない個体，あるいは皮下にその疸跡のある個体が合 せて $20 \%$ 程度存在する。

第 5 歩脚は，第 4 歩脚の出現したと同じように腹部に 接するよらにその基部両端に突起状に現われるが，その 長ざは極めて短い(Fig. 4, Ab-4)。

基節棘は第 3 顎脚，第 1 3 歩脚に在るが第 3 顎脚に それを欠く個体が僅かにある。第 2 頻脚，第4 歩脚には 基節棘は認められない。腹部は伸長するのみで変化しな w。

第 5期 (Fig. 8) 頭甲の長さと幅との比は 1:0.543 で，更に細長くなり，それとともに变化し続けた頭甲後

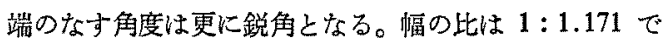
胸幅が頭甲幅を洎駕する。
触角は，第 1 ，第 2 ともに伸長し，第 1 触角には外鞭 が認められるが (Fig. 2，A-5)，節によつての区分はな い。分節は外鞭基部扣よびその基部と触角基部との中間 に各々出現して，第 1 期で既に存在した触角基部の分節 と合せて 3 分節となる。第 2 触角は変化しない (Fig. 2, A-5)。

第 2 小顎, 第 1 3 顎脚, 第 1 3 步脚には殆んど变 化はないが第 4 歩脚は伸長し，その外肢には 1 分節とそ の先端側に遊泳棘毛を具元 (Fig. 4, Ab-5)，形態的仡 殆んど完成する。

基節棘は，第 3 顎脚，第 $1 \sim 3$ 歩脚以外には認められ ない (Fig. 9)。

第 5 歩脚は笑起状で，腹部も伸長するのみで共に形態 的な変化はない。

第 6 期 (Fig. 10) 頭甲の愊はその長さの約 1/2で, $1: 0.514$ となり, 頭甲幅と胸幅との比は $1: 1.360$ で, 更にそれらの幅の差は大きくなる。なおここの期の特徽 として類角が出現する。

触角は，第 1 触角に扎いて更に 1 分節が出現して4分 節となり，その外鞭は稍々伸長するが，節によつての区 分はない。第2 触角は変化しない(Fig. 2，A-6)。

第 2 小顎, 第 1 3 顎脚, 第 1 4 歩脚はともに相対 的に成長するのみで形態的な変化はないが，基節棘は突 起状に変化して棘としては認め難くなる。第５歩脚は僅 かに伸長してコンマ状となる外は形態の変化はない 


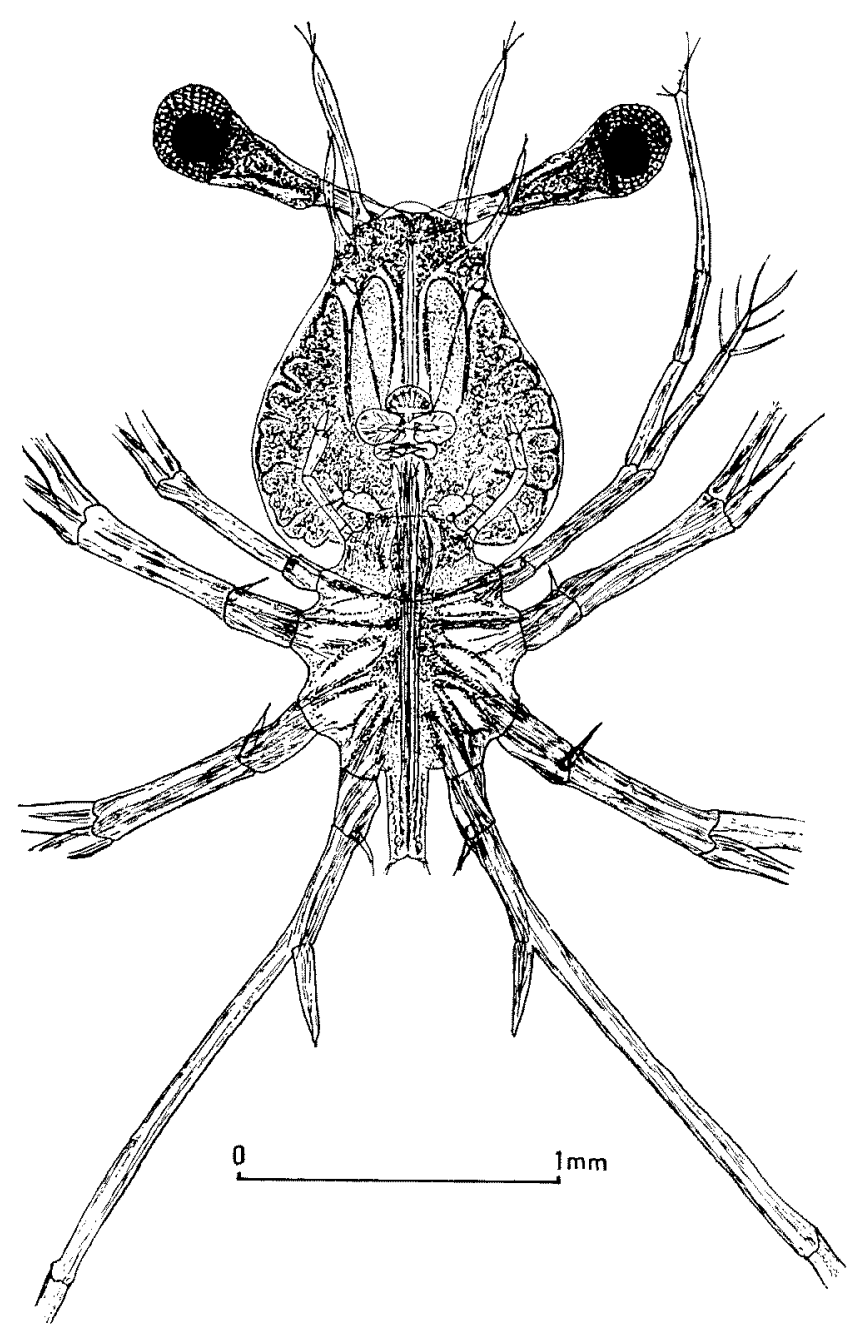

Fig. 6. Second stage of Panulirus japonicus phyllosoma in ventral view.

(Fig. 4, $\mathrm{Ab}-6)$ 。

腹部む伸長するのみで腹肢, 尾脚，尾節および関節は 皮下にも珰められない。

胸部後方の山秋は，左右の第 4 步脚基部を結ぶ線が腹 部の約 $1 / 2$ の位固にあつて稍々凹みが顥著となる。

第 7 期 (Fig. 11) 第 1 触角住伸長するのみで変化し ないが，第 2 触角はその中間より稍々先端側と基部に各 1 分節が出現する。

頭甲の長さと幅との比は $1: 0.485$ で，最小值を示し， 胸幅との比は $1: 1.574$ で胸幅は頭甲幅の約 1.6 培とな 万。

第 2 小頻, 第 $1 \sim 3$ 頸脚叔よび第 1 4 歩脚住伸長す るのみで形態的な変化はない。

第 6期において突起状に変化した第 3 䫛脚括よび第 1
〜3 步脚の基節棘は共に消失してその痕跡当認方机な $<t_{5}$

胸部後方の山文は，左右の第4 步脚基部を結ぶ線と腹 部徭端が注ぼ一致して蹎著となる。

腹部は，大部分の個体に変化は見られないが，痕跡状 に皮下に関節，尾脚の珰められる個体がある。

第 8 期（Fig. 12）第 1 触角は，之の外鞭が節によつ て区分され，僅かに伸長する外忹目立つた形態変化はし ない。しかし，第 2 触角には更に 1 分節が出現して3 分 節となるが (Fig. 2，A-8） 4 分節の個体が若干ある。こ れらは分節と同時に伸長して第 1 触角とほぼ同じ長さと なる。

頭甲の長さと幅の比は $1: 0.488$ で，第 7 期まで小さ かつた輻の伸長率は增大へと変化する。頭甲と胸部との 


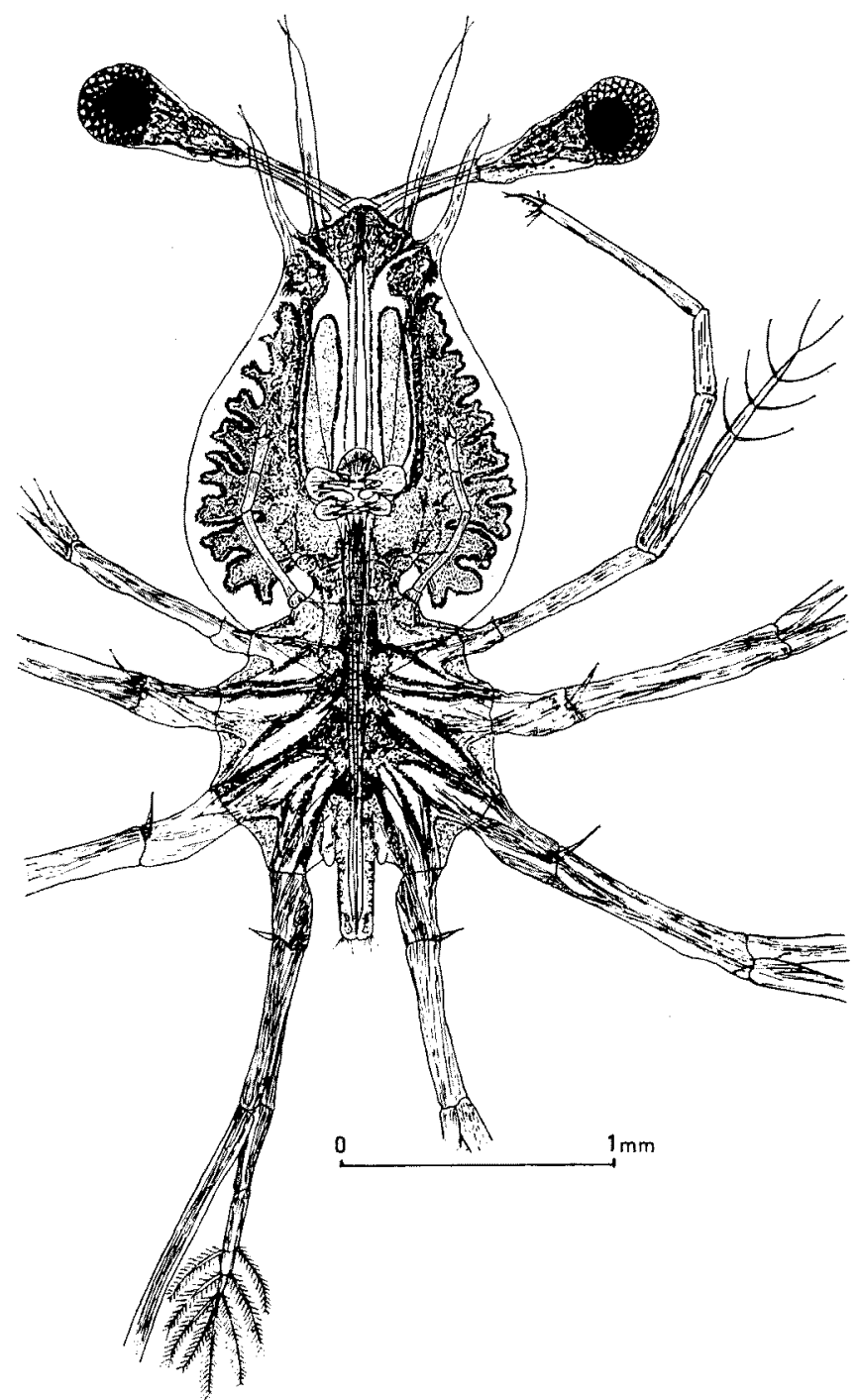

Fig. 7. Third of Panulirus japonicus phyllosoma in ventral view.

幅の比は $1: 1.625$ で，胸部幅の比は最大值を示す。

第 2 小靧は，形態に変化が生じ始める(Fig. 3，M8)。

第 1 嚬脚は伸長するのみで形態变化はしない。第 2 顎 脚には外肢の出現する徵候が見られるが，分節は衿めら れない(Fig. 3， M-8)。

第 3 顎脚お゙よび第 1〜4歩脚もまた伸長するのみで目 立つた変化はない。しかし少数の個体では第 5 歩脚が伸 長して基節の区分が認められる。

腹部は，その中央部がくびれて後半の愊が広くなり尾 脚が出現する (Fig. 4，Ab-8)。その内外葉の区分は不
完全ではあるが切れ込みによつて認められる。しかし， 関節，腹肢は小数の俔体に出現し，大部分は皮下にそれ らの痕跡らしいものが認められる。

第 9 期 (Fig. 13) 第 1 触角は伸長するのみで形態的 な変化はないが第 2触角は之の長さに括いて第 1 触角を 凌鴐し，鞭状部の基部に分節が生じ，合計 4 分節とな る(Fig. 2, A-9)。

頭甲長と幅の比は $1: 0.519$ で長さの伸長率の高か た第 8 期恋でとは逆にこの期から輻の伸長率が高くな $り$ ，頭甲はその外縁と胸部の外穔が交叉寸る第 3 顎制の 基部に扎いて角張り，頭甲後端の角度も增大乙始める。 


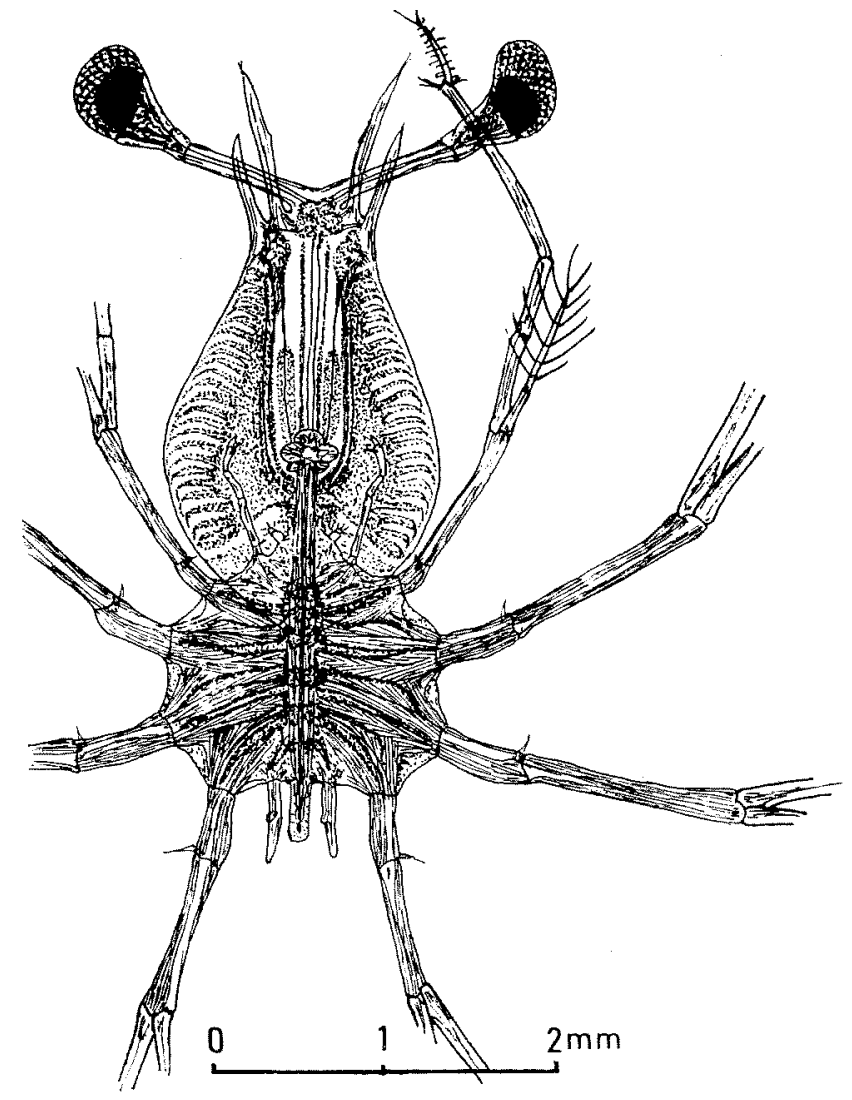

Fig. 8. Fourth stage of Panulirus japonicus phyllosoma in ventral view.

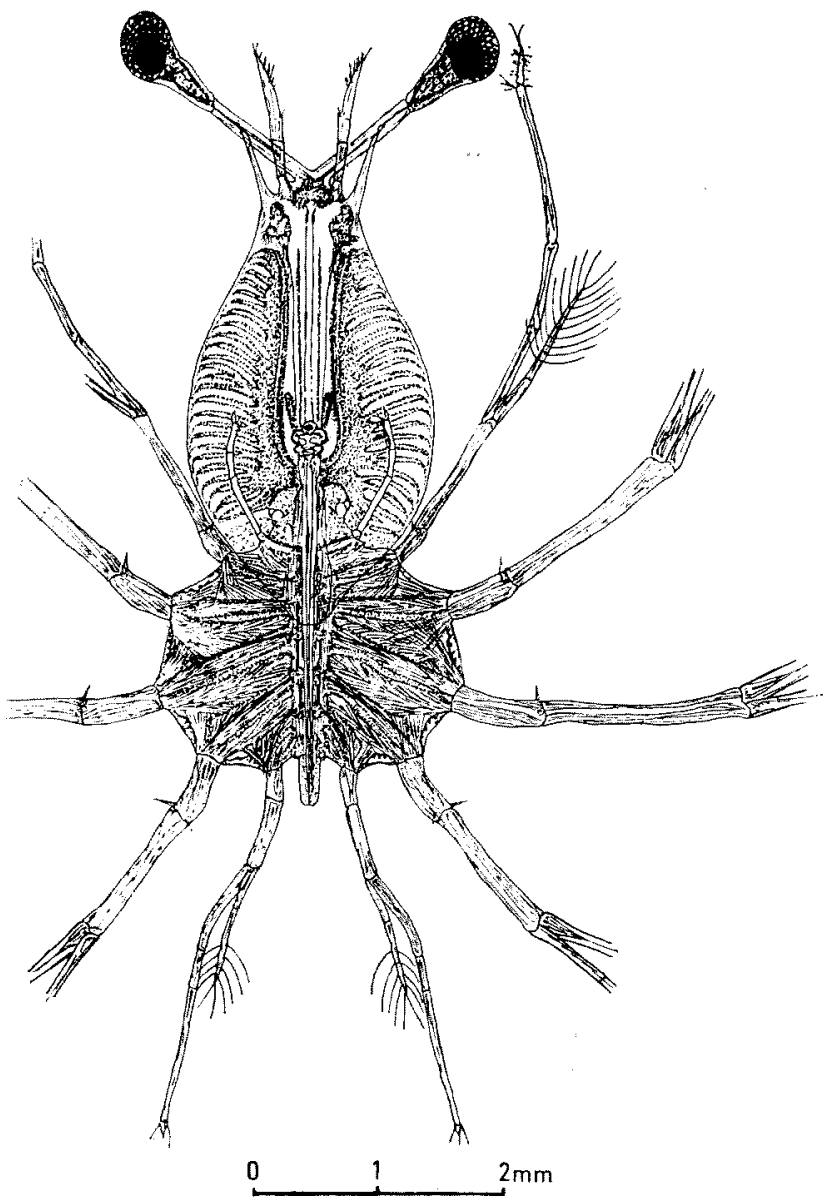

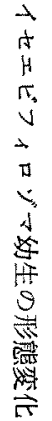

Fig. 9. Fifth stage of Panulirus japonicus phyllosoma in ventral view. 


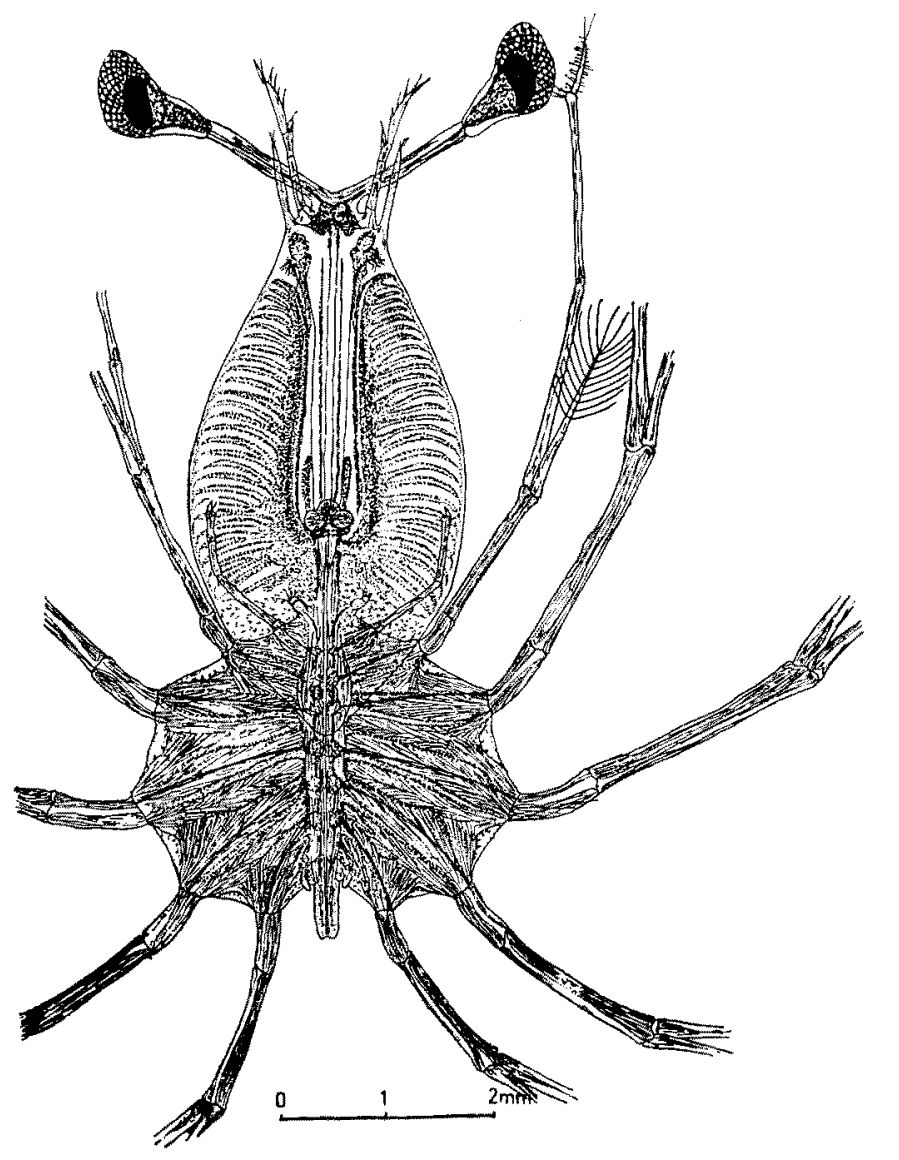

Fig. 10. Sixth stage of Panulirus japonicus phyllosoma in ventral view.

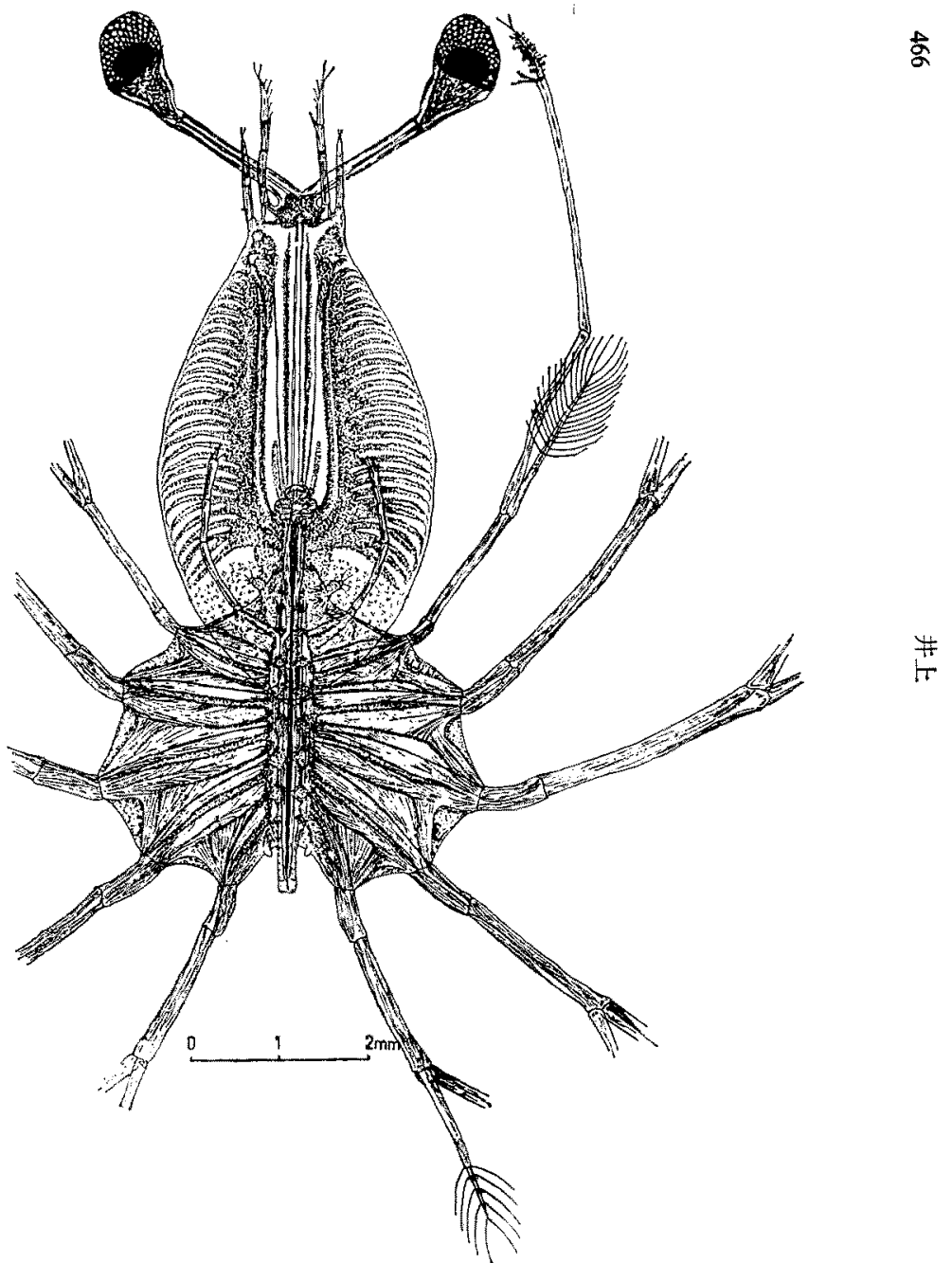

Fig. 11. Seventh stage of Panulirus japonicus phyllosoma in ventral view. 


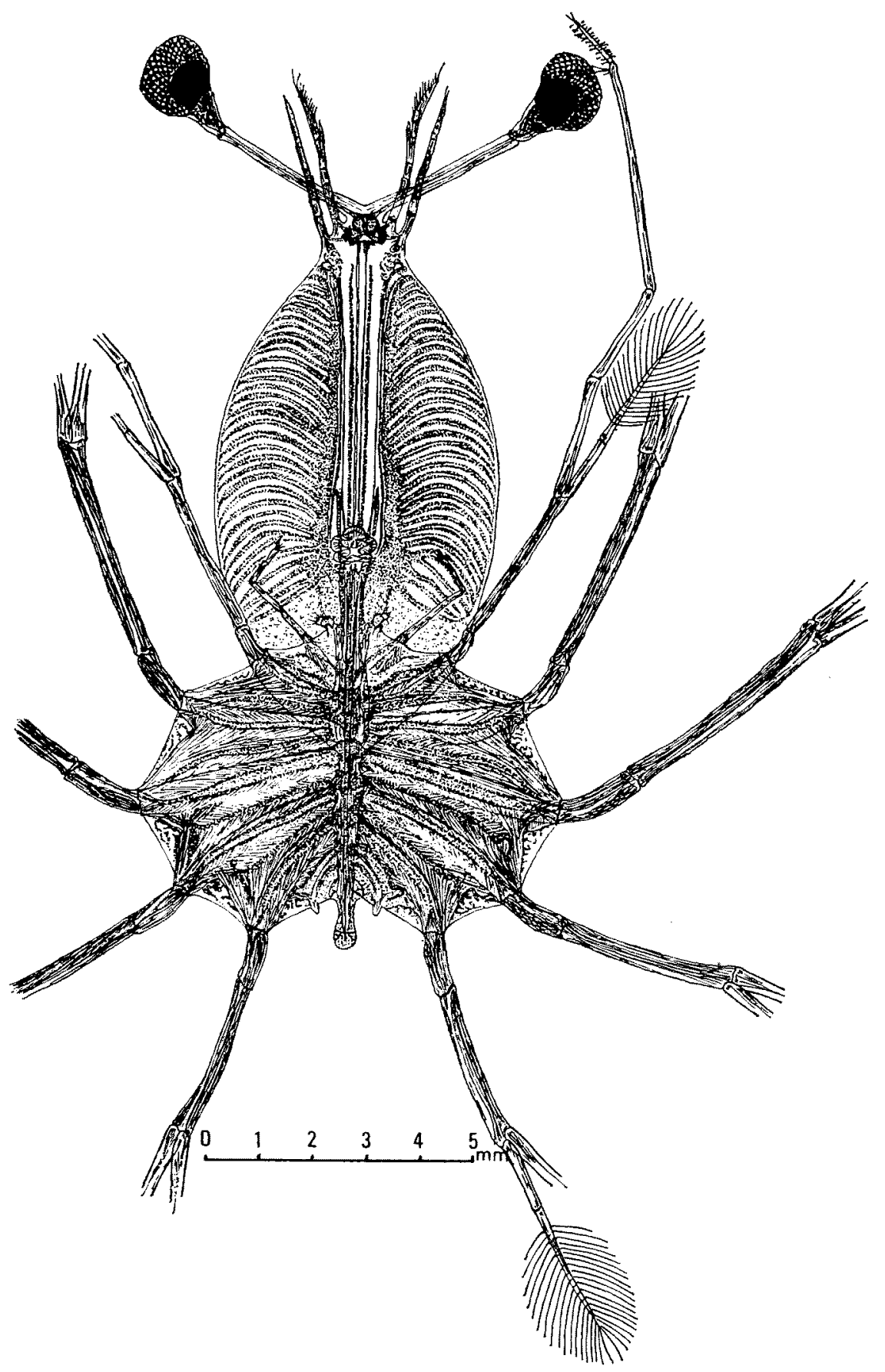

Fig. 12. Eighth stage of Panulirus japonicus phyllosoma in ventral view. 


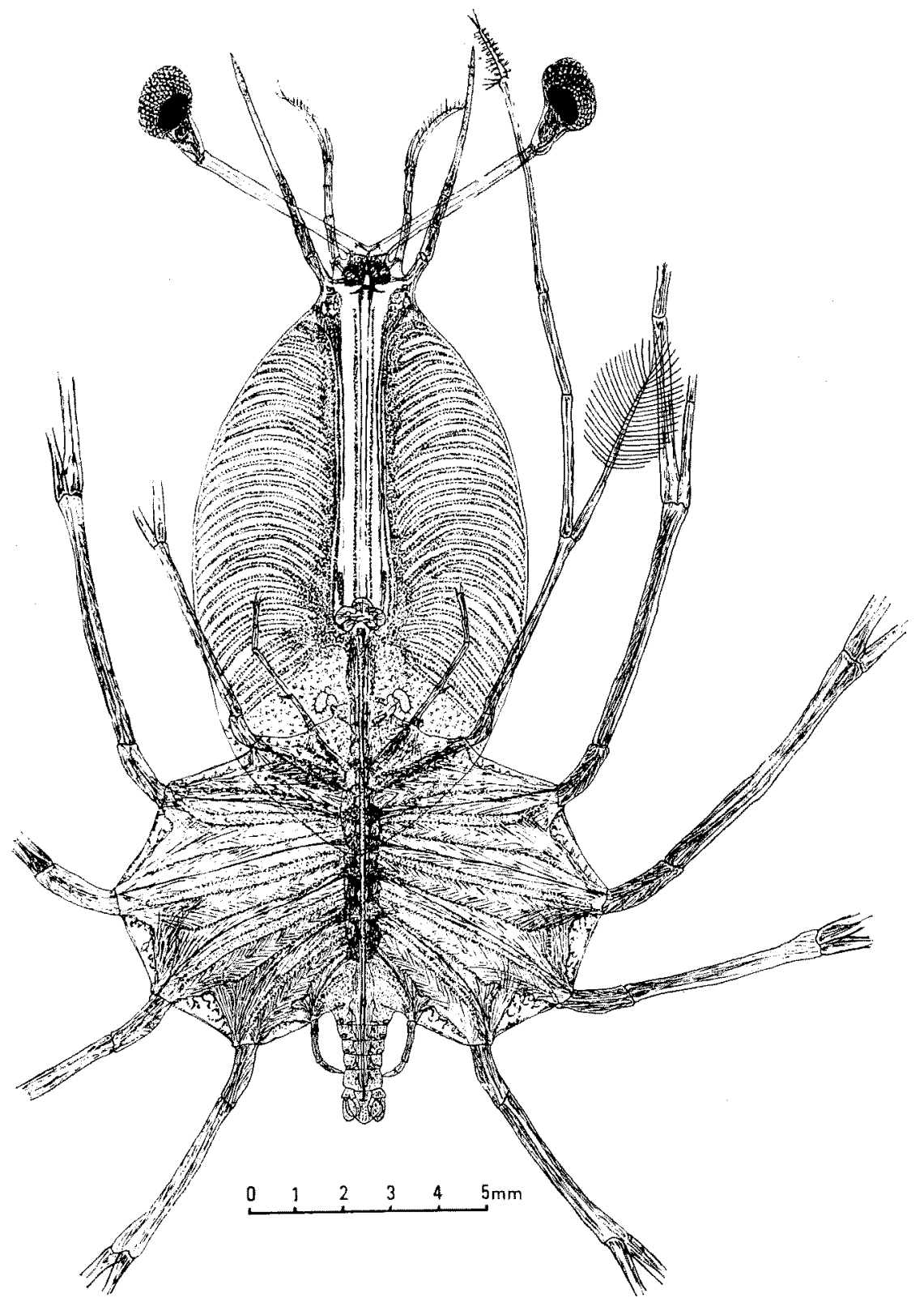

Fig. 13. Ninth stage of Panulirus japonicus phyllosoma in ventral view. 


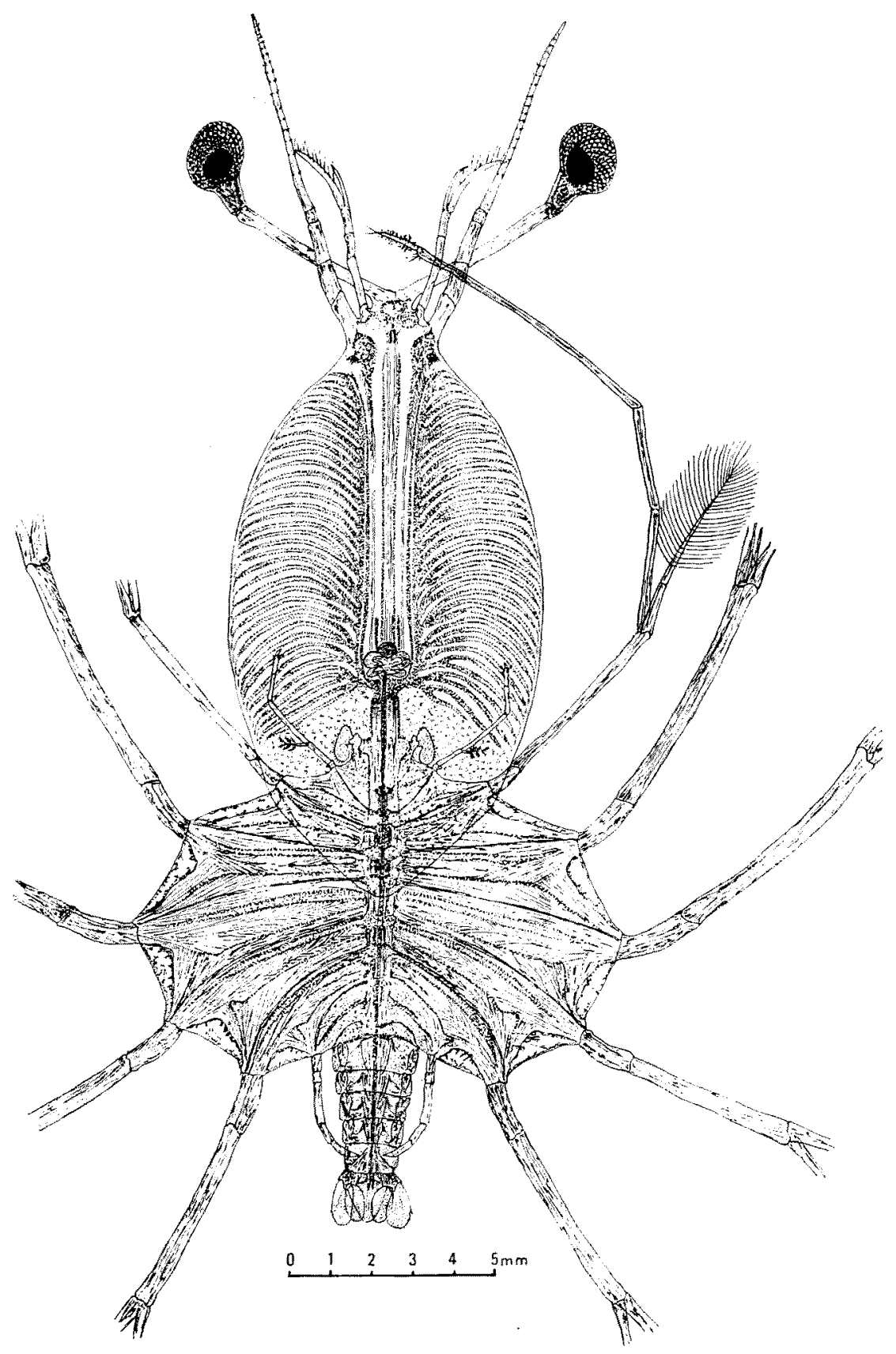

Fig. 14. Tenth stage of Panulirus japonicus phyllosoma in ventral view. 


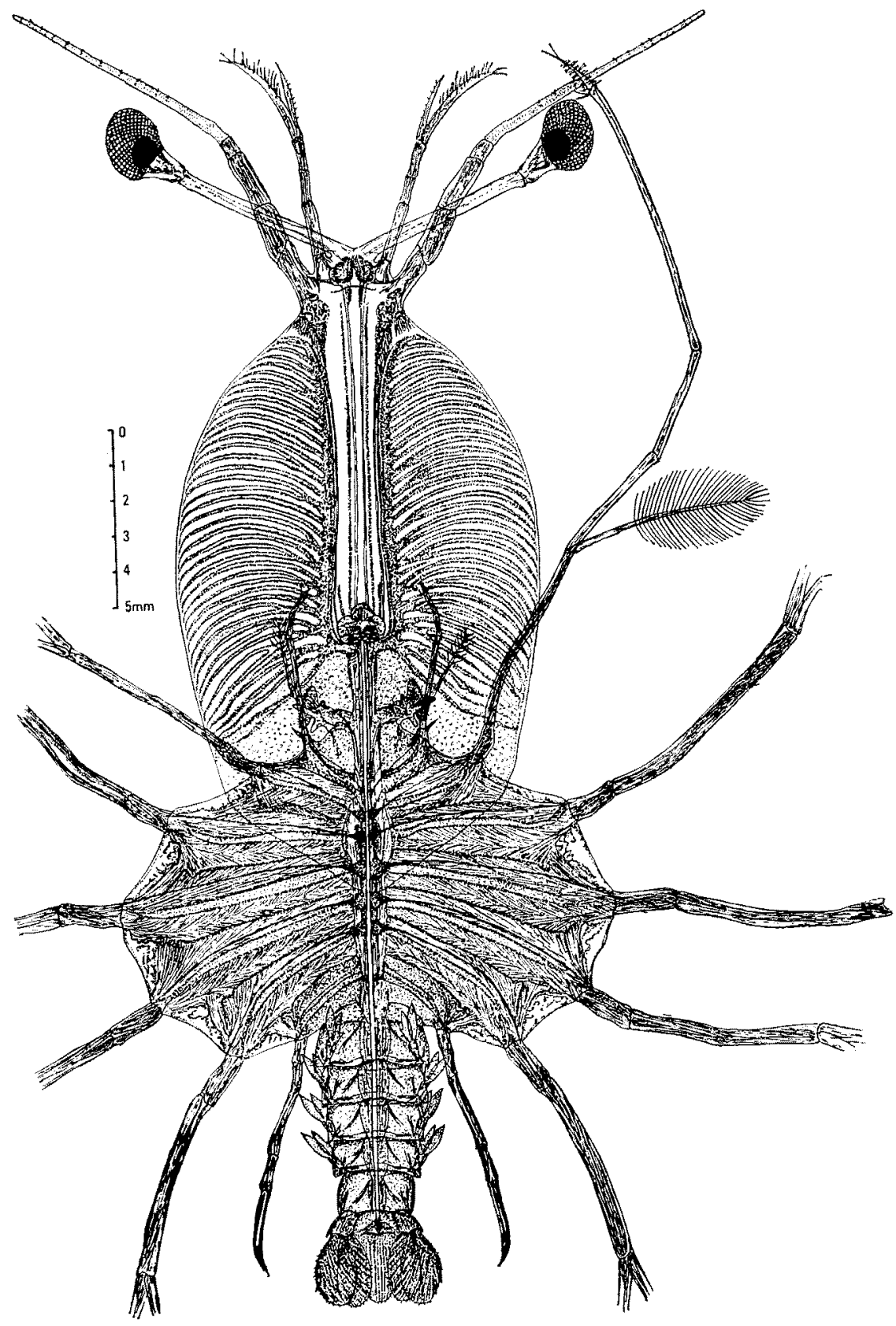

Fig. 15. Eleventh stage of Panulirus japonicus phyllosoma in ventral view. 
第 6 期で出現した額角には目立つた変化はない。頍甲と 胸部の幅の比は $1: 1.555$ で，第 8 期に比校して胸部の 幅の比が小さくなる。

第2小顎には外肢の伸長が認められ，その外縁に列毛 を有する (Fig. 3，M-9)。

第 1 罰脚は僅か、伸長するのみで形態の变化はない。

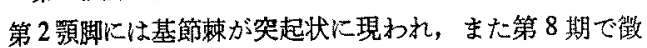
候の見られた位置に突起状の外肢が出現するが節による 区分括よび分節は見られない(Fig. 3，M-9)。しかし極 少数の個体では基節棘, 外肢とむにそれらを欠くものが ある。

第 1 4 歩脚は第 3 顠脚とともに形態の变化はない が，第 5 歩脚は伸長して 4 節に分節し，その長さは腹部 と同じか稀く短い。しかしその長さが腹部の約 $1 / 2$ で, 基節のみの個体が少数見られる。

腹部は，尾節，尾脚がほ济完成する。腹肢は，乞の起 源が 1 4 節の各左右下端に出現し，外葉と内葉との区 分が認好られる (Fig. 4, Ab-9)。

第 10 期 (Fig. 14) 第 1 触角は，その外鞭の伸長する 外は形態的変化は殆んぞない。第 2 触角はその鞭状部の 伸長が影著で, 第 1 触角の約 2 倍となり, 踈状部には小 楝の発達が目立つ。

頭甲の長ざ幅は $1: 0.524$ で, 頭甲幅と胸幅との比 は $1: 1.479$ となり, 第 9 期に比殡して胸部との幅の比 が更に小さくなる。

第 2 小頱の形態梳变化し，第 1 頻啩は伸長するととも に外肢が突起状に出現する (Fig. 3，M-10)。

第 2 顎期は，外肢が伸長し，一つの節とその先端側に 3 対の遊泳獭毛が出現する。宗た外肢基部に節が生じ， 來節と長節とが区分されて分節となり，形態的炕はほほ 完成する。しかし基節棘は突起状で变化しない。

第 3 颗朋および第 1 4 歩脚は伸長するのみで变化は なく，第 5 歩脚俚第 9 期と同じように腹部と同じか稀名 短いが，1 分節が生じて合計 5 分節となり，指節も楒め られ，ほ济完成する (Fig，4，Ab-10)。

䧗部は関節に上つて区分され，尾節，尾脚は完成し， 尾脚内外雨葉と尾節の両側緣には各々一つの小棘を有す ๖。

腹肢は伸長して内外葉が明瞭となり，大部分の個体の 内葉に惊不明瞭ではあるが appendix interna が認めら れ，腹肢の方向が後向きであつたり，体中線に詨して直 角方向に拡げた状態であつたりすることから，腹肢と之 の内外葉の関節はこの期に汪注完成する。

第 11 期 (Fig. 15) 触角は, 第 1 触角外鞭の伸長之第 2触角频状部の伸長以外飞は变化はない。 頭甲の長さと融の比は $1: 0.567$ で，第 10 期より更 に幅の比は增大する。頭甲幅と胸幅との比は $1: 1.316$
で逆に小さくなる。それに伴なつて頭甲後端の角度は拡 大し，胸部外縁と交叉する頭甲处縁部は第 10 期に比較 して更に危ばる。

第 2 小頸は，その外肢外縁の列毛が更に密となり，第

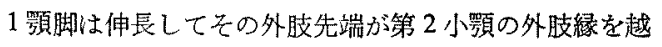
える (Fig. 3, M-11)。

第 3 彭脚は，基節棘が明瞭となり，外肢も発達して 6 $\sim 7$ 対の遊泳肢毛を具点る。

第 3 顎脚就よび第 $1 \sim 4$ 歩脚には顛著な変化は見られ ない。第 5 歩脚も腹部と同程度か稀ヶ長くなるのみで殆 んど変化しない。

腹部は更に発達し，屈伸運動が矨察されるから機能的 にも㾁㜔完成する。

以上の結果を取りまとめると Table 1 となる。

\section{論㦈}

飼育によつて得たフィロゾマの形態の発達変化は，あ る体長で変化するはずの幾つかの附属器官の5ち, 不特 定なある附属器官において発澾变化の不充分な個体があ り, 発現の仕方にずれを生ずる。むた附属器官のみなら ず，体長においても何回かの脱皮を絽返して次期の体長 に達するが，附属器官括よび形態の発達変化に上つて仕 分けした結果では 11 の stage に分けられ，各 stageの 形態について特徽を述べた。

ところで，多くの研究にある stage の決め方は，ある stage (N) から次の stage $(\mathrm{N}+1)$ への形態変化が一回 の脱皮によつて起ることを前提として採集物を形態の変 化によって仕分けした結果であり, JOHNSON ${ }^{9)}$ は, 自然 採集した Panulirus interruptus のフィロゾマについて, その形態の発達变化から 11 の stage を経過するとした

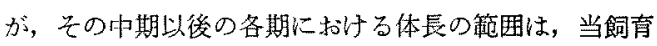
に上る各期の体長範囲之同じよらにかがり大い。P. inflatus ${ }^{11)}$ についても同样である。

なお当研究では, 形態变化の幄れた個体住各期の体長 範囲のうち，小さい側汇片よる傾向がある。すなわち第 3 期以後において，一回の脱皮では体長の伸び，形態変 化ともに次第に不充分となり, 次期の形態へ変化する⿱ で何回かの脱皮を繰返すよらになる。同時に各期に相 当する体長の範囲が拡大するので, 自然域に括いても各 期の体長範团のうちで小さい側の個体は，各期の特改之 しての形態が充分に発澾变化していない可能性が考兄ら れる。しかし初期の第 1 3 期では instar ごとの体長 々形態の発達変化ははぼー定する。したがつて当研究の 䈌用では，飼育に上る特殊な環境に上つて起る現象なの か，自然域に掓てて普通にあり得る現象なのかを確かめ ることはできなかつたが，自然域に抋いても stage と instar とはこれらの点で一致しない疑いがある。 
Table 1. Summary of certain distinguishing characteristics

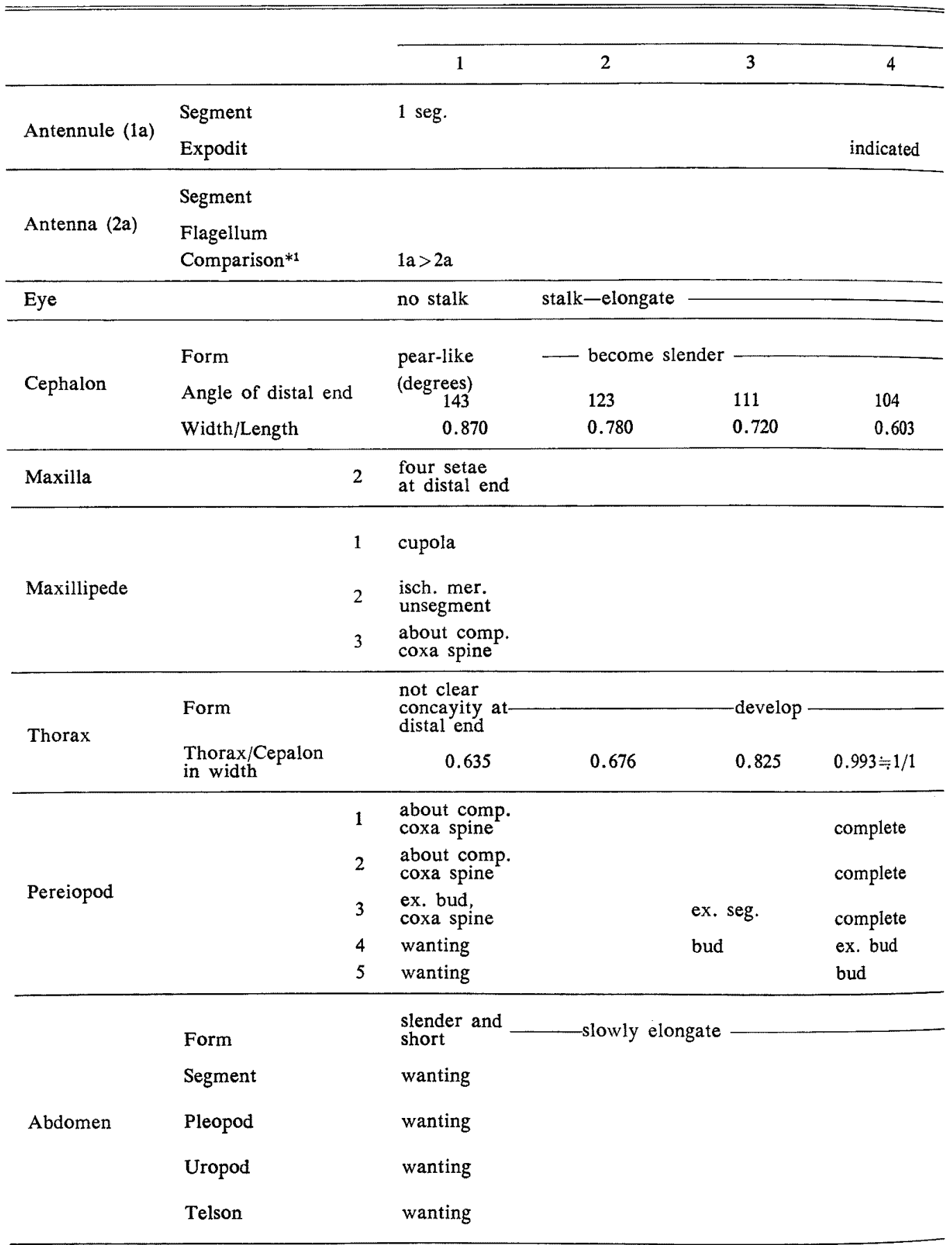

\footnotetext{
*'; the length of antennule and antenna, *2; the point of intersection of cephalon contour and thorax contour, ex; exopod, maxi;
} 
of phyllosoma stages in panulirus japonicus

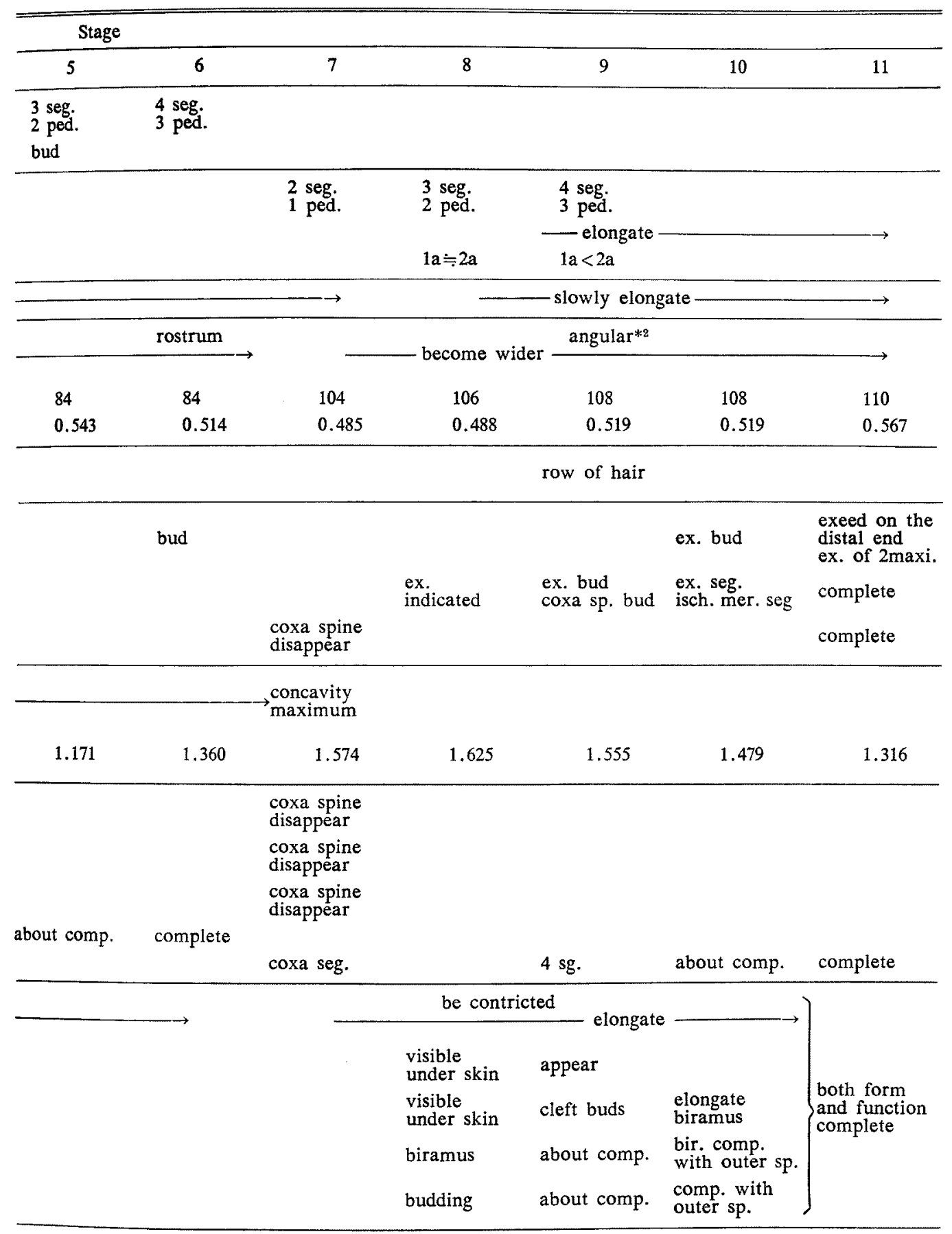

maxilla, seg; segment, ped; peduncle, isch; ischium, mer; merus, fla; flagellum, sp; spine. 
著著 (3) $^{32}, 1963$ 年に 6 回脱皮後の体長 $4.3 \mathrm{~mm}$ ま でのフィロゾマの飼育結果について報告し，大島》の Form-Eをイ七ェビのフィロゾマであると仮定したが， この Form E は当研究による胸幅と頭甲幅との比, 第 6 7 期以後にお汁る第 3 頡脚，第 $1 \sim 3$ 歩脚の基節栜の 消失などの形態变化拉よび後期に打ける第 2 触角の長さ から険討すると、これはイセエビではなく，他の锺のフ ィロゾマであると判断されるのでこのことについての

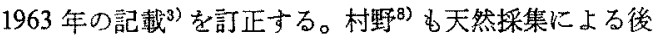
期フィロゾマの 5 formについて記載し，大島の Form Eはイせエピのフィロゾマではないことを指適してい る。この飼育結果からは, むしろ大身の Form-F がイ セエビフィロゾマに近似する。しかし村野の Form A とともに，その頭甲後端は棈円であるが当研究によつて 得た平均体長 $16.8 \mathrm{~mm}$ の第 9 期以後のフィロゾマは, 頭甲の外縁と胸部の外縁とが交叉寸る部分で頭甲は角ば り，また相対的に頭甲幅が㹨いために，頭汁の長さと幅 との比, 胸部と頭甲との幅の比は, 上記の Form A・F よりかなり小さい。したがつて Form A・F を直にイ セエビフィロゾマと決めるにはな和疑問が残る。

イ七エビ属のフィロゾマの期数については, Panulirus argus について LewIS $^{14)}, P$, interruptus について JOHNSON ${ }^{9)}, P$, pencillatus $K つ い \tau$ PrAsad and TOMP1 ${ }^{122}, P$, cygnus について GeORGE ${ }^{13)}, P$, japonicus について村野”が，採集によつて得心標本からそれぞれ 11 期であるとし， な大飼育に上つて得た第 1 期まで の各体長と大島が天然採集によつて得た Form-E をイ セエピフィロゾマと仮定して野中ら゙が 者ら ${ }^{3)}$ は，6回脱皮後までの標本を使つて 14 期とした。

ところで，これまでにイセエビ属のフィロゾを飼育 てレプエルルスに変態させ，最終期のフィロゾマを直接 に確諗した記録はない。立た，当研究に㧊いても果し得 なかつたが，イセエビ属の採集摽本を扱つた上述の研究 者らは, 形態の特致と付属器官の発達変化を指標として 採集物を類別した結果に㧍いて，同種に分類された標本 の最大型の体長とそれの付属器官の形状ならびにそれら とプエルルスの体長・体形・付属器官の形状との関係, および既に知られている種のフィロゾマと対比すること によつて推测し, 最終期の体長は, 採集物中の最大型, または期数との関係化沶いてその最大型を求めて，体長 $30 \mathrm{~mm}$ 前後であるとしている。

道津ら ${ }^{18)}$ は，採集した最終期のウチワエビ Ibacus cilialus とかオバウチワエビ I, novemdentatus を飼育 して，注らく幼生に変態させだ。これら 2 種は，変態に 際して，頭甲は口を中心収縮し，ウチワエビでは体長 に执いて約 20\%，頭甲で約 15\% 収縮したとしている。 な抢气の報文中の Fig. 1 扰上び Fig. 12 から求める
と，道津らが指摘しているように，腹長では逆に約 $38 \%$ 伸長することになる。

イセエビのプエルルスでは，著者の採集した 28 尾の 体長は $19.2 \sim 21.4 \mathrm{~mm}$, 平均 $20.1 \mathrm{~mm}$ で, 体形, 特 に頭甲は 5 角筒状で，その長さは約 $8 \mathrm{~mm}$ であり，腹 長は $12 \mathrm{~mm}$ 前後である。これらは，イセエビ属の他の 種のプエルルス ${ }^{9)}$ と極端に変らない。

したがつて，上記のウチワエビ属と同じょうに，変態 に際して伸縮があればフィロゾマの体形から察して頭甲 長は収縮し，腹長では伸長すると考えられる。これらの ことは，上述の研究者らに扒いて体長 $30 \mathrm{~mm}$ 前後をつ ィロソマの最終期としたことの根拠の一つとなつている と推測される。

なお，続報で詳細に報告するが，当研究によつて得た 結果では，期数と体長・腹長との関係は，ともに Brooks の法則のうち $(1 / L) \cdot(d L / d N)=\alpha$ が成り立ち, $L=\beta e^{d N}$ に適合するので， 12 期を想定してその体長お゙よび腹長 を試算すると, 体長は約 $40 \mathrm{~mm}$, 腹長では $13 \mathrm{~mm}$ と なる。

体長については，税所15)とよつて Panulirus $\alpha$ および $r$ として各々体長 $43.5 \mathrm{~mm}, 38.1 \mathrm{~mm}$ のフィロゾマが 採集されているのでこれらのプェルルスの体長は不明 ではあるが，現知識に执いては，体長によつて最終期の 大きさは説明しがたい。

腹長では, プエルルスの腹長と同じか, やや大きい值 となるが，変龍が生活様式の変化することへの形態の適 応と考えると，ウチワエビと同じように变態際して腹 部が発澾伸長することは，イセエビに叔るブエルルス の生態からすると充分に推測できる。このように考元る と、イセエビのフィロゾマについては 12 期はあり得な いことになる。

次に，イセエビ属に関する上記研究者らの記截と当研 究とに批いて名Stage の体長・付属器官の発達経䋨を比 較すると，種の異なることによる若干の違いはあるとし ても, 基本的には相違しない。そのうち, 当研究で得た 体長 $29.6 \mathrm{~mm}$ の標本に打注る付属器官, 特にその腹部 は，最終期とされている諸記载のそれらとよく一致する ので, 上記の研究者らによる諸記載に習うと, 当研究で 得た体長 $29.6 \mathrm{~mm}$ のフィロゾマは, プエルルスに变態 する最終期と考光られる。

しかも，この標本は，腹部の屈伸運動と尾脚の開閉が 雄察されることから機能的に腹部は汪ば完成していると い方る。

以上のことを総合すると，イセエビのフィロゾマ期は 11 期に分けるのが至当であるら。 


\section{謝辞}

1956 ’72 年の長い期間に至つて終始有蓝なご教示と 激励方賜的り，本報告の校閱を戴いた東京大学大島泰雄 名篦教投・平野礼次郎教授に哀心から礼申し上げま †。

また，諭議を通じて貴重な情報を提供された浄网水試

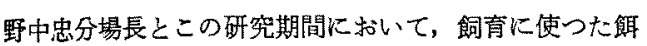
料の採集，䬲料としての仔魚の飼青などフィロゾマの飼 苔に関して協力を得た今井利為ならびに小林良雄, 土屋 久男, 戸田久仁男, 田内 大, 近山通正, 池田武男, 五 十嵐正明，小川万次，高橋亥宣，加藤紀子，佐々木良， 山口喜行の諸氏に対し，記して謝意を表する次第であ る。

\section{要 旨}

1956 ’72 年の期間に，フルテミヤとそれに採集した 各種の你魯, ヤムシ，人工受精によつて得たスズキ、、 コガレイの仔魚などを添加して期料とし，イセエビのフ ィロゾマ奻生を飼育し次の結果を得た。

1）飼育によつて得たフィロゾマの形態変化は，ある 体長で変化するはずの幾つかの付属器官のらち, 不特定 なある部分についてその発達変化が不充分であつたり， また体長においてす何回かの脱皮を綠り返して次期の体 長に達するなど必ずしる規則正しくない。特に 3 回脱皮 以後に拈いてその㑯向が強い。このことが飼育による特 殊な環境によつて生じたものであるかは明らかでない が，程度の差はあるとしても instar と stage とは自然 域においても一致しない疑いがある。

2）飼育によつて得た 112 標本について，第 1.2 触 角, 第 2 小類, 第 $1 \sim 3$ 顎脚, 第 3 歩脚外肢の発達, 第 4.5 歩脚の出現とその発達変化，基節梀の消長，腹部 における関節，腹肢，尾節，尾脚などの出現発達および 頭甲の長さと幅の比，頭甲辐と胸幅の比などを指標にす ると 11 期に分類することができる。各 stage の特徽を Fig. $2 \sim 15$ と Table 1 k示した。

3) 著者ら イセエビのフィロゾマと仮定し，飼育によつて得た初期 フィロゾマの体長と Form E の体長とからその期数を 14 期としたが，この飼育によつて得た標本によると
Form E はイセエビではなく，他の種のフィロゾマで あることが判つたので，このことについて訂正する。

4) 大島の Form F がイセエビのフィロゾマに近似 するが，体長の該当する各 stage の形態について検討す ると村野 ${ }^{8)}$ の Form A とともに Form F を直にイセ エビフィロゾマとすることにはな搷問が残る。

5)この飼亩によつて得た $29.6 \mathrm{~mm}$ のフィロゾマ は，他の種についての記戴などから最終期と考えられ る。したがつてイセエピのフィロゾマは 11 期に分ける ことができる。

\section{参考文献}

1）神奈川県水座試監場：神奈川県水試報告，盗料 No. 36, 99, 120, 146, (1967-'70).

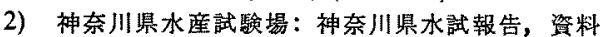
No. 189 (1972).

3) M. Inoue, and M. Nonaka: Bull. Japan. Soc. Sci. Fish. 29, 211-219 (1963).

4) 井上正昭: 日水誌, 31, 902-906 (1965).

5)野中忠 - 大島秦雄 - 平野礼次郎：水産增殖, 5(13), 13-15 (1958).

6) 大島泰雄：水産学会報, 9, 36-44 (1942).

7) M. Murano: Bull. Plankton. Japan. Commemoration Number of Dr. Y. Matsue, 129-137 (1967).

8) M. Murano: Pubi. Seto Mas. Biol. Lab., XIX (1). 17-25 (1971).

9) M.W. Johnson: Proc. Calif. Acad. Sci. 4, 29(1), 1-19 (1956).

10) M. W. Johnson: Bull. Scripps Inst. Oceanogr. Univ. of Calif., 7(6) 413-462 (1960).

11) M. W. JoHnson: Scripps Inst. Oceanogr. Univ. of Calif., Crustaceana, 10, Part 1, 3147 (1966).

12) R. R. Prasad and P.R.S. TAmpI: Proc. Nat. Inst. Sci. India., 23 B, 48-67 (1957).

13) R.W. George: Jour. of Roy. Soc. of West. Australia, 45 (4), 100-110 (1962).

14) J.W. Lewis: Bull. Mar. Sci. Gulf and Carribean, 1, 89-103 (1951).

15) 税所俊郎：捱児大学, 水産学部紀要, 15, 177239 (1966).

16)道津喜衛・田中於先彦・座島洋一一妹尾邦義: 長崎大学, 水㘱学部研经報告, 21, 195-221 (1966). 